\title{
Nakagami Kenji's 'Writing Back to the Centre' through the Subaltern Narrative: Reading the Hidden Outcast Voice in 'Misaki' and Karekinada
}

\author{
Machiko Ishikawa \\ University of Tasmania
}

\begin{abstract}
The aim of this thesis is to give a post-colonial reading of selected narratives by Nakagami Kenji (1946-1992). Nakagami was the first Akutagawa Prize winning novelist from Japan's outcaste Burakumin group. Through the production of narrative about this subaltern community, Nakagami confronted the exclusionary systems of hegemonic Japanese thought and the structures created by these systems which deny the principle and lived experience of 'difference.' Borrowing the post-colonial concept of 'writing back' to the hegemonic centre from the work of Bill Ashcroft, Gareth Griffiths and Helen Tiffin's The Empire Writes Back, this article will analyse Nakagami's 'Misaki' (1976, The Cape), and its sequel, Karekinada (1977, The Sea of Withered Trees). The principal focus will be on Nakagami's representation of the hidden voice of those on the margins of Japanese society.
\end{abstract}

This approach will position the Burakumin as 'subalterns' to the mainstream Japanese society on the basis of Antonio Gramsci's view of the group. The analysis of 'Misaki' and Karekinada will begin with an investigation of Kishū Kumano as a site on the margins of mainstream Japanese society. In analysing these two novels as subaltern narratives, close attention will be given to Nakagami's use of intertextuality particularly with oral kishu ryüritan folklore.

\section{Keywords}

Nakagami Kenji, Post-colonialism, Subaltern, Burakumin, Kishu ryūritan

\section{Introduction: Nakagami Kenji and Post-Colonial Theory}

The aim of this thesis is to give a post-colonial reading of selected narratives by the Burakumin writer, Nakagami Kenji (1946-1992). Nakagami was the first Akutagawa Prize winning novelist from Japan's outcaste Burakumin group and also the first post-war born writer to win this prestigious award. Through the production of narrative about this subaltern community - that is, a community of subordinate rank through 
contingencies such as class, gender, location, sexual orientation, ethnicity or religion ${ }^{1}$ - Nakagami confronted the exclusionary systems of hegemonic Japanese thought and the structures created by these systems which deny the principle and lived experience of 'difference'. My general project is to foreground Nakagami's insistence on 'difference' as a strategy to dismantle the exclusionary hegemonic thought which produces discrimination in society.

In terms of the relationship between the mainstream society and the outcaste Burakumin group, we can consider a post-colonial reading as one that examines Burakumin cultural elements - in this case, the texts of Nakagami - and how these have been shaped by resistance to the exclusionary socio-political processes of mainstream Japan. In The Empire Writes Back (1989), Bill Ashcroft, Gareth Griffiths and Helen Tiffin note that the term 'post-colonial' is used to explain all of the cultural elements that have been affected by the European imperial process from the moment of colonisation to the present day. ${ }^{2}$ It can be argued that mainstream Japan has taken an attitude similar to that of imperialism towards minority groups, including the Burakumin, the group of which Nakagami was a member.

Ashcroft, Griffiths and Tiffin also explain the common features of post-colonial literature:

[Post-colonial literatures] emerged in their present form out of the experience of colonization and asserted themselves by foregrounding the tension with the imperial power, and by emphasising their differences from the assumptions of the imperial centre. ${ }^{3}$

Nakagami's literature emerged from the present circumstances of the Burakumin through their experiences as marginalised outcastes. In his writings, the 'difference' of the Burakumin is also depicted by 'foregrounding the tension with the [central] power', and by 'emphasizing their differences from the assumptions of the centre'.

The focus of the analysis to follow will be Nakagami's Akutagawa Prize winning story, 'Misaki' (1976, The Cape), and its sequel, Karekinada (1977, The Sea of Withered Trees). These two stories are part of the fictional trilogy known as the Akiyuki saga (The Akiyuki Saga): 'Misaki', Karekinada and Chi no hate, shijo no toki (1983, The Ends of the Earth, Supreme Time). The trilogy takes its name from the eponymous

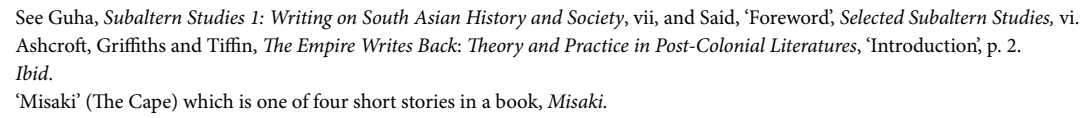


protagonist, generally acknowledged as modelled to some extent on Nakagami himself. Nina Cornyetz asserts that, in terms of contemporary intellectual, political, historical, narratorial, and philosophic criteria, the human dramatic narratives of the Akiyuki saga are without a doubt the best of Nakagami's fictional texts. ${ }^{5}$ Each of these works is set in a peripheral slum-like community of the Kumano region of Kishū, which is the writer's own birth place.

This approach will position the Burakumin as subaltern to the mainstream Japanese society. It will also interpret Nakagami's critique of the mainstream as 'writing back' to the hegemonic centre from which the illiterate Burakumin had once been excluded. Drawing on a statement by Salman Rushdie (b.1947), a writer whom Nakagami regarded as a peer, ${ }^{6}$ to the effect that 'the Empire writes back to the Centre', Ashcroft, Griffiths and Tiffin argue that 'writing back' is the way in which postcolonial - that is, subaltern - writers and texts respond to and engage with mainstream literature. Noya Fumiaki points out that, since Nakagami's narratives were set in Kumano, i.e. the 'dark side' of Japan, ${ }^{7}$ his material spontaneously contained characteristics of 'postcolonial' literature. Noya holds Nakagami in high esteem for the latter's representation of marginality in novels written during the 1970s prior to the theorising in Japan of any post-colonial critical perspective.

The analysis of 'Misaki' and Karekinada provided below will begin with an investigation of Kishū Kumano as a site on the margins of mainstream Japanese society. Knowledge about Kishū Kumano is essential to a reading of Nakagami's narratives because this material provides background to the subaltern status of the writer's characters by depicting the 'otherness' of this area, long regarded as on the periphery of Japan. In analysing these two novels as subaltern narratives, close attention will be given to Nakagami's use of intertextuality with non-mainstream oral kishu ryüritan ${ }^{8}$ folklore from Kishū Kumano which contain traces of subalternity.

\section{Motives for Writing of 'Misaki' and Karekinada}

Because of the writer's background, scholars often interpret Nakagami's literature as representative of the Burakumin experience. However, it should be noted that this background was not known when Nakagami's work first came to public notice in 1976 with 'Misaki'. In fact, Etō Jun (1932-1999), one of Japan's most influential post-

\footnotetext{
Cornyetz, 'An Ambivalent Masculinist Politics', Dangerous Women, Deadly Words: Phallic Fantasy and Modernity in Three Japanese Writers, p. 206.

6 In his intervew with an Indian novelist Usha Subraminian, Nakagami regards Salman Rushdie as his 'raibaru'. In Japanese, this term signifies a 'peer' rather than 'rival'. See Nakagami, 'Interview: Usha Subraminian', America, America, p. 215.

7 Noya, 'Nakagami Kenji to sekai bungaku' (Nakagami Kenji and World Literature), Kokubungaku kaishaku to kanshō: bessatsu, p. 32.

8 See Section 'Kishu ryüritan: The Hidden Outcast Voice'.
} 
war literary commentators, proclaimed Karekinada, to be the culmination of seventy years of Japanese naturalist literary expression. ${ }^{9}$ The nature of Nakagami's writing, in common with that of post-colonial literature, confronts the hegemonic power to discriminate against the socially oppressed, particularly the Burakumin. Initially read as narratives of a peripheral slum-like community of Kishū Kumano, however, 'Misaki' and Karekinada were not regarded as representations of Burakumin society until 1978, the year Nakagami made his Burakumin background public.

Recognition of this point is critical when analysing the writer's primary motive for text production. In his first published works, at least, Nakagami focuses on a representation of the silenced voice of the oppressed rather than engaging with buraku mondai (Burakumin issues). Most preceding novels about Burakumin - such as Shimazaki Tōson's Hakai (1906, The Broken Commandment) and Noma Hiroshi's Seinen no wa (1971, A Circle of The Youth) can be read as novels addressing Burakumin issues. ${ }^{10}$ Unlike these non-Burakumin writers, Nakagami avoids using the term, Burakumin, to depict the marginalised people. Nakagami despised this term, which he regarded as regulated by the hegemonic power of the government, the Buraku Liberation League and some 'money-making' contractors who promoted the dismantlement of the hisabetsu buraku (Burakumin districts), ${ }^{11}$ including his own birth-place. ${ }^{12}$ For him, the use of the term signifies the exercise of the same political power as those who devised the post-war policy of modernisation. In other words, Nakagami regarded narratives by these non-Burakumin writers which engaged with Burakumin issues as strengthening the structure of the hegemonic centre.

\section{Kishū Kumano: 'The Country of Darkness' where the Losers have Settled}

In his travel journal, Kishū: kinokuni, nenokuni monogatari (1978, Kishū: A Tale of the Country of Trees and Roots), Nakagami portrays the Kishū region, which consists of Wakayama Prefecture, Mie Prefecture and Nara Prefecture in the Kii Peninsula, as 'the nation of darkness' where the 'losers' have settled. ${ }^{13}$ The word, 'losers', implies political

\footnotetext{
9 Etō, 'Bungei jihyō: Showa 52 nen 2 gatsu' (Literary Comment February 1973), Gunzō Nihon no sakka 24: Nakagami Kenji, pp. 142-45.

10 See Watanabe's argument in "Akiyuki to roji" (Akiyuki and the roji), Nihon kindai bungaku to <sabetsu> (Japanese Modern Literature and $<$ Discrimination $>$ ), pp. 133-58.

11 Hisabetsu buraku literally means 'discriminated community - hamlet'. In contemporary Japan, hamlet areas (buraku) which are the focus of status (or caste) discrimination are called hisabetsu buraku. This term came into use in Japan in the late 1950s and was adopted by the media and in academic circles in the 1970s. Today, the term dowa chiku (assimilation areas) is also used as a way of referring to hisabetsu buraku and these terms are used interchangeably. More precisely, dōwa chiku refers to hisabetsu buraku which have been designated by administrative agencies as being areas to which dōwa policies are directed. Excluding Hokkaido and Okinawa prefectures, there are six thousand such designated areas in Japan. People born in these areas are estimated to number about three million. Of six thousand hisabetsu buraku areas, a 1987 government survey designated four thousand six hundred and three as dōwa $c h i k u$. Consequently it is generally acknowledged that there are more than one thousand hisabetsu buraku which, for a range of reasons, remain undesignated and lie beyond the application of the government's dōwa policies. See Teraki, 'The Buraku Question.

12 Nakagami and Takahashi, 'Roji to shinwateki sekai no kōgaku', Nakagami Kenji hatsugen shūsei 5, pp. 87-106.

13 Nakagami,'Shūshō: yami no kokka' (Epilogue: The Nation of Darkness), Kishū: kinokuni, nenokuni monogatari, p. 292.
} 
losers who were regarded as the socially stigmatised such as ancient exiled nobles, rebellious farmers and modern anarchists and socialists. The expression, 'the nation of darkness', also suggests Nakagami's view of Kishū as a site that is juxtaposed against the hegemonic centre of Japan, the nation that operated under the brilliant auspices of the sun goddess. Kishū is geographically situated in a site that is the inverse of the ancient capital, Kyoto, where the Emperor, who is the symbol of hare, purity or glory, once lived. ${ }^{14}$ Traditionally, Kumano was known as a spiritual spot for healing fatal diseases such as leprosy. It was thus depicted in folklore and myth as a sacred yet ominous realm of death and revival inhabited by the marginalised and ostracised. ${ }^{15}$ Nakagami's representation of Kishū resonates with the etymology of Kumano which means 'field of bears' and 'hidden country'.

His essay, 'Watashi no naka no nihonjin - Ōishi Seinosuke' (1977, A Japanese Man on my Mind - Ōishi Seinosuke), also displays Nakagami's view of Kishū Kumano as a place that was historically 'left out in the cold' by the hegemonic centre:

\begin{abstract}
Kumano was the place to which the Emperor Jimmu came for Tōsei (the conquest of the East) and where, according to the Kojiki (712, Record of Ancient Matters), 'a large bear (could be seen) faintly moving around; then it disappeared. Then Kamu-Yamatö-Ipare-Bikö-Nö-Mikötö (the Emperor Jimmu) suddenly felt faint; his troops also felt faint and lay down. ${ }^{16}$ Kishū Kumano is always in darkness. Although situated close to the culture of the Kinki area, it is under the shadow of the Yamato Court. Through the Edo period and into the last days of the Tokugawa Shogunate, and even after the Meiji Restoration, the Kishū clan could not find their way into the halls of power. While it might sound exaggerated, Kumano has always been left out in the cold despite being featured in Japanese history since the time of ancient myth. ${ }^{17}$
\end{abstract}

The Kojiki was compiled in 712 to justify the hegemony of the imperial families of the time. ${ }^{18}$ Donald L. Philippi, the English translator of the Kojiki, notes that reference to the 'large bear' (kuma) signifies that the unruly deities of the Kumano mountains appeared in the form of a bear and cast a spell over the Emperor Jimmu and his men. When Jimmu was revived by a magic sword, the deities of Kumano were 'magically

14 Nakagami, 'Fūkei no mukō e' (Beyond Scenery: A Trip to Korea), Nakagami Kenji zenshū 15, p. 63.

15 Nakagami and Tomioka, 'Hatsunetsu suru Ajia' (Feverish Asia), Nakagami Kenji hatsugen shüsei 5, pp. 233-34. Also see Karlsson's discussion on Kumano in 'Introduction', The Kumano Saga of Nakagami Kenji, pp. 2-4.

16 Descriptions in parentheses are my annotations in this citation. I cited Philippi's translation of the Kojiki, retaining Philippi's macrons. See Book Two, Chapter 49: 'Emperor Jimmu and his troops sink into a mysterious slumber. As Taka-kurazi, obeying a dream, presents a sword to Emperor Jimmu, the unruly deities of Kumano are magically quelled.' Kojiki (Record of Ancient Matters), p. 167.

17 Nakagami, 'Watashi no naka no nihonjin - Ōishi Seinosuke', pp. 41-42.

18 See 'Kojiki', Daijisen, p. 960. The narrative of Jimmu tōsei is also written in Nihon shoki (720, The Chronicle of Japan). In this thesis, however, I focus on the Kojiki narrative which Nakagami cited in his essay, 'Watashi no naka no nihonjin - Ōishi Seinosuke', Yume no chikara, pp. 41-47. 
quelled' ${ }^{19}$ In the Kojiki, the people of Kumano are described as 'men with tails'. Philippi cites commentary suggesting that the early Japanese believed that indigenous people who lived in the mountains, given their 'primitive' stage of cultural development, were animal-like and were therefore referred to as having tails. ${ }^{20}$

Nakagami's view of Kumano ambivalently resonates with the derogatory assumptions made by those that conquered the people who fled to and were exiled or executed in Kumano. Noting that the Kii Peninsula, on which Kumano is located, is 'a peninsula of darkness', Nakagami observed that it was 'no mystery' ${ }^{21}$ that Kishū Kumano was the home of various groups who had rebelled against the hegemonic powers. This included those who fled to Kumano after being defeated in the Saika ikki (1577-1585, The Riot in Saika), an uprising in Saika against Oda Nobunaga (15341582). The rioters were a group among believers of Jōdo shinsh $\bar{u}$, derogatively referred to as the $I k k \bar{o} s h \bar{u}$ by the other Buddhist sects in Japan. This riot leader was a son of the governor of Saika Castle, Saika Magoichi (16th century), whose followers, armed with guns and trained in the art of ninja, were once of the most advanced military troops of the time.

\section{The Roji: The Site of Subaltern Narratives}

As previously noted, Nakagami avoids using modern terms related to the Burakumin in the Akiyuki saga. Kasuga - one of the hisabetsu buraku of Kishū Kumano that is the setting for the saga - is referred to as the roji (alleyway), a place occupied by people who live 'like insects or dogs.'22 This peripheral community includes long-standing residents and new comers such as Koreans and drifters. One of the main subjects of the Akiyuki saga is the dismantlement of the roji - the Burakumin homeland - during the modernisation and urbanisation of peripheral areas throughout Japan that occurred in the 1970s and 1980s. Nakagami's roji birth place, the Kasuga buraku, along with the hill that divided it from the developed area of Shingū City, was demolished as part of 1969-1979 Special Measures for Dōwa (social integration) Issue legislative reforms. Witnessing the dismantlement of his homeland, Nakagami wrote the Akiyuki saga between the mid 1970s and the early 1980s.

\footnotetext{
19 This part is written in the Kojiki as follows: 'At the very time that he (Jimmu) received that sword, all of the unruly deities in the KUMANO mountains were of themselves cut down'. Philippi notes in an annotation that 'the magic power of the heavenly sword was in itself sufficient to vanquish immediately all the unruly deities'. See Philippi, Book Two, Chapter 49, entitled 'Emperor Jimmu and his troops sink into a mysterious slumber. As Taka-kurazi, obeying a dream, presents a sword to Emperor Jimmu, the unruly deities of Kumano are magically quelled', Kojiki, p. 167.

20 Philippi, Book Two, Chapter 50 entitled, 'On the way from Kumano to Yamato. Emperor Jimmu is guided by a giant crow. The local earthly deities come to greet him, Kojiki, p. 170.

21 Nakagami, 'Watashi no naka no nihonjin - Ōishi Seinosuke', pp. 41-42.

22 Nakagami, 'The Cape, The Cape and Other Stories from the Japanese Ghetto, pp. 15-16.
} 
We have noted that at the time of publication of both 'Misaki' and Karekinada, Nakagami's Burakumin background had not yet been made public. ${ }^{23}$ The terms 'hisabetsu buraku' and 'Burakumin', therefore, never appear in these narratives. Nevertheless, through the use of the term roji, the text successfully conveys to the reader the marginalised circumstances of the people in Kumano, the 'hidden country' of ancient texts.

\section{The 'Matrilineal' Family Narrative: Writing Back to the Mainstream}

The ambivalence of the protagonist towards his complicated family relationships is a driving force behind the tragedy of the Akiyuki saga. Akiyuki's family background overlaps with and has a number of clear parallels to Nakagami's own. In this saga, Nakagami repeatedly narrates the past traumatic events of the 'matrilineal' family to explain the conflict that besets Akiyuki's family and also in order to display the significance of the past for the present. A summary of Akiyuki's family history is given below (See also Appendix: Akiyuki’s Family Tree).

Akiyuki's mother, Fusa, ${ }^{24}$ had five children with her first husband who was a resident of the roji. After the death of both her first husband and a son, she met 'that man' (Hamamura Ryūzō) who drifted into the community from the outside. Ryūzō, who was said to have been the arsonist who had set light to some areas of the roji, was condemned by members of the community as an 'uma no hone' (horse's bone). ${ }^{25}$ While Fusa was pregnant with Akiyuki, Ryūzō was arrested for gambling. Fusa left Ryūzō after discovering that he had made two other women pregnant. Akiyuki - and his two half-sisters, Satoko and Tomiko - were born while Ryūzō was in a prison. When Ryūzō returned to see his threeyear-old son for the first time, Akiyuki refused to acknowledge the man as his father. After leaving Ryūzō, Fusa met a new man named Takehara Shigezō. When Akiyuki was seven, Fusa and her youngest son moved to live with Shigezō and his son in a neighbouring town. Akiyuki's eldest half-brother, Ikuo, and half-sister, Mie, remained living in the roji. Ryūzō also returned to the roji where, through the dishonest exploitation of land, he established a successful lumber business. As a result, the roji residents scornfully referred to him as 'hae no kuso no ' (the King of Fly Shit). ${ }^{26}$ When Akiyuki was twelve, the behaviour of his half-brother, Ikuo, became violent and he often threatened to kill Fusa and Akiyuki. Amid rumours that Ikuo and Mie were having an incestuous relationship, Mie eloped with her brother's friend. Ikuo committed suicide at the age of twenty-four.

\footnotetext{
23 'Misaki' was published in 1976. Nakagami made his Burakumin background public in 1978. In 'Misaki', there is no particular place-name except Kishū to describe where Akiyuki's family lives. In Karekinada, many accounts of the geography, history and folklore of Kumano can be found.

24 In 'Misaki', Akiyuki's mother is called 'Toki'. Nakagami renamed her 'Fusa' in Karekinada and Chi no hate shijō no toki.

25 Nakagami, Karekinada, p. 27. Uma no hone (horse's bone) is a derogatory expression for a person of unknown background or parentage. See 'uma no hone', Kōjien, p. 228.

26 Nakagami, Karekinada, p. 27
} 
In the opening of 'Misaki', Akiyuki, too, is twenty-four years old and working in a road construction gang run by his brother-in-law's office in the roji. Ryūzō, whom Akiyuki calls 'that man', keeps watching him. Akiyuki's indignation towards Ryūzō is heightened when he hears a rumour that Ryūzō keeps his own daughter, Satoko, as a mistress.

Nakagami 'writes back' to the mainstream family ideology through the depiction of Akiyuki's 'matrilineal' family. As seen in the essay on his own family referred to above, Nakagami regards the 'matrilineal' family as deviating from the mainstream family i.e. the family of patriarchal society. From the viewpoint of modern Japanese family ideology, Fusa and Ryūzō are depicted as parents whose family suffers because they fail to function as the ideal pair of a respectable patriarch and ryōsai kenbo (good wife wise mother). ${ }^{27}$ The patriarchal family ideology on which these ideals are founded emerged as a part of the modern Japanese social hierarchy which saw the Emperor as the 'father' of the nation-state.

In his reading of Nakagami, Karatani Kōjin draws a line between the symbolic emperor system (shōchō tennōsei) and the system of emperor as the head of the nation state (kindai tennōsei). In the pre-modern era, with the shōchō tennōsei, the emperor was little more than a figure head. At the outset of the Meiji era, however, the introduction of the kindai tennōsei saw the emperor become the constitutional head of state. It was this system that instituted the modern patriarchal family system. In spite of the reforms which saw the end of the kindai tennōsei and a return to a form of the shōcho tennōsei in the post-war era, the pre-war hegemonic family ideology has persisted until today. ${ }^{28}$

In the context of the shōchō tennōsei as practiced during the Tokugawa Shogunate, both the Imperial family and members of Burakumin society were considered political losers by the hegemonic centre. Citing Ishio Yoshihisa, Karatani argues that the Kishū Burakumin originated from the segregation of rebels subdued during the $I k k \bar{o} i k k i^{29}$ by Oda Nobunaga and his successor, Toyotomi Hideyoshi (1537-1598). Later, the Tokugawa Shogunate instituted the segregated class as a social outcaste group. ${ }^{30}$ The contemporary operation of the shōchō tennōsei today positions the imperial family and the Burakumin at the vertical extremes of heaven and earth in terms of social status. Nevertheless, since both are excluded from the mainstream as embodiments of difference, Nakagami sees the relationship between the two as 'horizontal.'.1

\footnotetext{
27 The joint ideology of patriarchy and ryōsai kenbo was introduced to establish an ideal Japanese family in the process of modernisation during the Meiji era. See Koyama,'Ryōsai kenbo shisō no seiritsu' (Establishing an Ideology of Good Wife Wise Mother), Ryōsai kenbo to iu kihan (The Normative Standard of Good Wife Wise Mother), pp. 57-60.

28 Karatani, 'Hisabetsu-buraku no "kigen”' (The ‘Origin' of Hisabetsu Buraku), Sakaguchi Ango to Nakagami Kenji (Sakaguchi Ango and Nakagami Kenji), pp. 244-51.

29 The riots by the believers of $I k k \bar{s}$ shū were called $I k k \bar{o} i k k i$. Saika $i k k i$ is one of the Ikkō $i k k i$. Ikkō $i k k i$ were a frequent occurrence in the 16 th century. See 'ikkō ikki', Daijisen, p. 161. Also see my discussion of Saika ikki in the section of "Kishū Kumano: 'The Country of Darkness' where the Losers have Settled". 30 Karatani, 'Hisabetsu buraku no "kigen”, Sakaguchi Ango to Nakagami Kenji, pp. 244-51.

31 Nakagami, 'Nihon no futatsu no gaibu' (The two exteriors of Japan), Nakagami Kenji zenshū 15, p. 584.
} 
While the 'otherness' of the imperial family, however, is coded in and thereby validated by the Constitution, Burakumin 'otherness' is regarded as flawed. Through depicting the subaltern family on the periphery of Japanese society in the Akiyuki Saga, Nakagami displays the exclusionist ideology of the Japanese mainstream. He also successfully brings the narrative of this subaltern group into mainstream discourse.

\section{The Repetitive Narrative of Family Tragedy: Intertextuality with Ancient Myths}

The Akiyuki saga narrative is underlain by a repetition of family tragedy. When depicting the conflict in Akiyuki's family, Nakagami draws on forms that the author regards as providing narrative archetypes of family tragedy, including Western myths, Japanese myths and kishu ryūritan narratives from Kishū. In 'Misaki', for example, Nakagami references the tragic Greek tale of Electra, who helped her brother, Orestes, kill both their mother and their mother's lover who had murdered their father ${ }^{32}$ Nakagami explained that he wished to depict Akiyuki's sister, Mie, as a Japanese Electra and the brother, Ikuo, as an inverted Orestes. ${ }^{33}$ Ikuo, who kills himself rather than seeking revenge, is defined as an 'inverted Orestes' while Mie can be interpreted as a sister who unconsciously manipulates her brothers (Ikuo and Akiyuki) in order to subvert and metaphorically kill her mother. We might note that in the Akiyuki Saga, however, Mie's matricidal tendencies are overshadowed to some extent by the protagonist's Oedipal desire for patricide.

A main theme of the Akiyuki Saga is the son's constant challenge against the paternity. The narrative of the struggle for supremacy by the patriarch is a key element of the cyclic repetition of the family. The Akiyuki Saga can be interpreted as representing the conflict between maternity and paternity, a conflict that continually impacts upon the protagonist. The rejection of the three patriarchs - Ryūzō, Ikuo and Akiyuki - by the matriarch Fusa suggests a narrative of their defeat by the maternal society of the roji. For them, affiliation with the hegemony of the roji (i.e. mother) signifies an attempt to gain its power of 'production' and 'fertility'. However, their ambivalence towards the 'mother' implies a simultaneous desire for matricide as retaliation for their exile from the supremacy of the patriarch.

Many critics have noted various aspects of Akiyuki's sensibility for 'the repetition of family tragedy. ${ }^{34}$ In this power struggle between the matriarch and patriarch,

32 See Sophocles, 'Electra', The Internet Classics Archive.

33 Nakagami, 'Fūkei no mukō e: Kankoku no tabi', Nakagami Kenji zenshū 15, pp. 60-61.

34 See Yomota, 'Kishu no shūen' (The End of Nobility), Kishu to tensei: Nakagami Kenji, pp. 154-55; Watanabe, 'Majikasa ni tsuite (Of Closeness)', Itoshisa ni tsuite (Of Affection), pp. 21-27; Iguchi, 'Kakusei to datsuryoku - Nakagami Kenji (Revival and Languor - Nakagami Kenji)', Kiki to tōsō: Ōe Kenzaburō to Nakagami Kenji (Crisis and Fight: Ōe Kenzaburō and Nakagami Kenji), pp. 85-89 and Karatani, 'Sanjussai, Karekinada e' (At the Age of Thirty, to the Straits of Withered Trees), Sakaguchi Ango to Nakagami Kenji, pp. 263-67. 
fratricide is a constant theme. In 'Misaki', when a cousin, Yasuo, murders his brother-inlaw, Furuichi, Akiyuki instinctively links the mortal relationship between the pair to his own relationship with the now dead Ikuo. In Karekinada, too, the inevitable repetition of this narrative is depicted through Akiyuki's identification with Ikuo, and his murder of his younger half-brother Hideo, his father's favourite son. Akiyuki realises that, by this act, he has repeated Ikuo's intent towards himself:

Akiyuki thought of Ikuo. Ikuo was his half-brother. When he thought of this fact, he was astonished to realise that at the time [when Ikuo was trying to kill him] Ikuo had the same feelings and circumstances that he himself had now. Standing in the dusk and soaking in the sunlight which still remained in the sky, he felt his eyes shining gold. I will kill you [Hideo], Akiyuki thought. Ikuo had thought [the same thing] at that time. Ikuo's eyes at that time were Akiyuki's eyes now. ${ }^{35}$

Akiyuki's abrupt (toppatsu-teki) ${ }^{36}$ murder of Hideo occurs on the night of the bon festival, the night on which the traditional dance ballad of Kyödai shinjū (a brother and sister double suicide) is sung. After killing his half-brother, Akiyuki identifies himself with both his eldest brother (Ikuo), who wanted to kill Akiyuki, and his younger brother (Hideo), whom Akiyuki kills. ${ }^{37}$ Ultimately, however, through his murder of Hideo, Akiyuki realises that, rather than being murdered by Ikuo, he has killed himself. (Ikuo no kawari ni Akiyuki wa, Akiyuki o koroshita). ${ }^{38}$

Incest is another cyclic theme of the narrative. Towards the end of 'Misaki', Akiyuki buys a prostitute who is rumoured to be his half-sister, Satoko. Even though he is unsure whether or not she is his real half-sister, Akiyuki and Satoko's narrative repeats the incest narrative of Ikuo and Mie. We will see that Akiyuki's committing incest is a deliberate strategy to outrage his father.

As when he committed incest with Satoko, Akiyuki expects Ryūzōs paternal anger to be unleashed by news of the death of his favourite son, Hideo. Akiyuki further expects that Ryūzō will express remorse for his own lustful life that has resulted in the failed offspring that commit these heinous acts. However, Akiyuki's incestuous and fratricidal challenges to Ryūzōss authority are all in vain. Although Akiyuki wishes to break away from and deny his family genealogy, it is clear that, in spite of Akiyuki's role in Hideo's death, Ryūzō bears no malice towards his murderous son.

35 Nakagami, Karekinada, pp. 111-12.

36 Ibid., p. 258

37 Nakagami, in fact, discusses this in terms of the Biblical tale of Cain and Abel. See his interview with Zimmerman in 'In the Trap of Words: Nakagami

Kenji and the Making of Degenerate Fictions', Ōe and Beyond: Fiction in Contemporary Japan, pp. 133-34.

38 Nakagami, Karekinada, p. 264. 
The family tragedies and characters depicted in the Akiyuki saga echo the local folklore about the subversion of morality such as an incestuous brother and sister's double suicide and riots ( $i k k i)$ by rebellious samurai. It is useful to examine Nakagami's use of such subaltern (Burakumin) folklore in his family narratives in greater detail.

\section{Kishu Ryūritan: The Hidden Outcaste Voice}

The issue of repetitive traumatic human relations is linked to Nakagami's representation of Kishū Kumano as a 'country of darkness' with a cyclic history of marginalisation by the hegemonic centre since the time of ancient myth. This is particularly evident in his use of subaltern folklore, kishu ryūritan (legends of exiled nobles, criminals and pilgrims), ${ }^{39}$ which tell of tragic relationships and also of political defeats by the hegemonic centre.

Many features of kishu ryüritan resonate with the history of subaltern groups identified by Antonio Gramsci, as 'necessarily fragmented and episodic'. ${ }^{40}$ Gramsci continues as follows:

There undoubtedly does exist a tendency [towards] unification in the historical activity of these groups but this tendency is continually interrupted by the activity of the ruling groups [...]. Subaltern groups are always subject to the activity of ruling groups, even when they rebel and rise up. [...] Every trace of independent initiative on the part of subaltern groups should therefore be of incalculable value for the integral historian. ${ }^{41}$

Gramsci's focus on subaltern history evokes Nakagami's focus on kishu ryūritan. For Nakagami, kishu ryūritan has 'incalculable value' because it resonates with the 'trace' identified by Gramsci that contains the hidden voice of those, like the Burakumin, who have been marginalised by 'the activity of the ruling groups'. Ashcroft, Griffiths and Tiffin support Gramsci's claim that, in spite of the fact that it is the elite narrative that becomes the 'official' version of history, the history of the subaltern classes is as complex and as significant as the history of the dominant classes. ${ }^{42}$

\footnotetext{
39 Kishu ryūritan (kishu '貴種: noble', ryūri '流離: wandering', tan '譚: narrative') is the theme of narratives and folktales about wandering (often exiled) gods, nobles, criminals and pilgrims. The term was firstly applied by Orikuchi Shinobu (1887-1953), in his Nihon bungaku no hassei Josetsu (1947, An Introduction to the Emergence of Japanese Literature) to identify narratives of gods who were wandering in an utsuho bune (a hollow ship). See 'kishu ryüritan' in Nihon daihyakka zensho. In Köjien, the term is defined as stories about wandering noble heroes who overcome difficulty with help from animals or women. Examples of the genre include the Kojiki narratives of Okuninushi-no-mikoto, Yamato-takeru-no-mikoto, the Hikaru-genji stories given in the 'Suma' and 'Akashi' chapters of Genji monogatari (A Tale of Genji) by Murasaki Shikibu (11th century), in addition the story of Odysseus in The Odyssey. See 'kishu ryūritan' in Kōjien, p. 575.

40 Gramsci, 'Notes on Italian History', Selections from the Prison Notebooks, p. 54.

41 Ibid., pp. 54-55.

42 Ashcroft, Griffiths and Tiffin, Post-colonial Studies: The Key Concepts, p. 216.
} 
In Nakagami's narratives, there are numerous 'episodic' kishu ryūritan about those vanquished in political battles who fled to and then remained in, or who were exiled to or executed in, Kishū Kumano. These include the tales of Arima-no-miko (Prince Arima) (640-658), ${ }^{43}$ the 12th century Taira clan (Heike ${ }^{44}$ and the losers of the 15 th and 16th century Ikko ikki. These and similar tales have been passed down from generation to generation as a confirmation of the social stigma experienced by these individuals and groups. By adapting 'episodic' Burakumin folklore in his narratives, Nakagami 'writes back' to the hegemonic centre and its 'official' history which has excluded the 'voice' of the subalterns.

This section will discuss Nakagami's use of these folk narratives - which comprise the area's rich oral history - in Karekinada. Particular emphasis is given to the Kyōdai shinjū song and the 16th century legend of the rebellious samurai and defeated leader of the Ikkō ikki, Saika Magoichi.

\section{Kishu ryūritan 1: Kyōdai shinjū}

Until the 1970s, the Kyōdai shinjū folksong, which depicts the tale of an incestuous brother and sister, was sung during the bon ${ }^{45}$ festival in Kasuga buraku ${ }^{46}$ In his essay 'Fūkei no mukō e: Kankoku no tabi' (1983, Beyond Scenery: A Trip to Korea), Nakagami explains his use of Kyōdai shinjū in Karekinada:

Although when writing I was unaware, I regard Karekinada as a novel that breaks the secret code of the Kyödai shinjū dance ballad. I myself probably comprehend the Karekinada narrative through interpreting the Kyōdai shinjū text. ${ }^{47}$

In summary, the Kyōdai shinjū ballad gives an account of a brother, Monten, who lives in Kyoto and who falls in love with and wastes away pining for his sister, Okiyo, who lives in Gōshū (the traditional name of Shiga prefecture). Although initially shocked when she learns of her brother's love, Okiyo eventually agrees to sleep with her brother on the condition that he kills her husband who is a mendicant monk. In the end, Monten commits suicide in Kyoto after mistakenly killing Okiyo who pretends to be the monk. The murder occurs in Gōshū on the Seta Bridge, a metonym for the border between the centre, i.e. life, and the periphery, i.e. death. The words of the song are as follows:

43 Arima-no-miko (Prince Arima, 640-658) is the son of the Emperor Kotōku. He was convicted of high treason and executed in Kii. The Manyōshü (8th century, The Collection of Ten Thousand Leaves) features two short poems composed by Prince Arima immediately before he dies. See 'Arima-no-miko', Daijisen, p. 90.

44 The Taira clan (Heike) came into power in the late Heian era and was overthrown in 1185. See 'Taira', Daijisen, pp. 1616-17.

45 Bon is a Japanese Buddhist festival that takes place in August during which people show respect to the dead. See 'bon', Köjien, p. 2224.

46 Zimmerman, 'Brother-Sister Love and the Creation of Akiyuki', Out of the Alleyway, p. 86.

47 Nakagami, 'Fūkei no mukō e: Kankoku no tabi', Nakagami Kenji zenshū 15, p. 60. 
Here in Nishijin town in Kyoto,

Monten, the brother, is twenty-one,

Okiyo, his sister, is nineteen,

Brother Monten falls in love with his sister

Pining for her, he then falls ill

Eating only two of three meals each day

Then two become one

Until he no longer consumes even one full meal

Okiyo, Okiyo

Mother calls her daughter again and again

Do you call me, Mother?

Please visit your brother who lies so ill

At her mother's request, Okiyo visits her brother

Quietly slides open the indigo-coloured door

Taking three steps forward and one step back

She prostrates herself before her brother, hands palms down on the floor

How do you feel, my brother?

Should I call a doctor? Should I bring medicine?

Monten, however, replies

I need neither a doctor nor remedy

A night with you, my sister, will make me well

On two pillows and three futon

My illness would be cured with a night spent together

Only one night - I beg you - dear Okiyo

Hearing her brother, Okiyo is shocked

Whatever do you ask, my brother?

Since we are siblings

People who heard this would call us beasts

If our parents heard this they would kill us

If my friends heard this, I would be deeply ashamed

There is a suitable woman to become your wife,

There is a suitable man for my husband, too

My nineteen year old husband is a wandering priest

If you kill this man

We will sleep together forever

I will be your wife for evermore 
Upon saying this Okiyo departs

She dresses her hair and makes-up her face

Then puts on a white silk kimono

From the wardrobe that was a gift from her parents

Donning her long black over-kimono

She three times winds the simple obi about her waist

Tying firstly a knot at the front

That she then briskly spins to the back

Stepping into her simple sandals

And taking her long bamboo flute

She walks across Seta Bridge playing the flute

Her face concealed completely by the straw hat of a wandering priest

Spying this figure, Brother Monten thinks

That must be my sister's husband

I must kill him to make Okiyo mine

He fires six shots at the form on the bridge

As the shots ring out a woman screams

Who are you? Forgive me!

Cries Monten, rushing to her side

He removes the hat to see the face

His sister Okiyo has sacrificed herself

My sister deceived me

If I now die, too, we can end our lives together

Here in Nishijin town, in Kyoto, there were a brother and sister

What a pitiful tale of double suicide ${ }^{48}$

Kyōdai shinjū is a variation of the Gōshu ondo which is the generic name of a bon dance ballad with a particular rhythm and melody, variations of which are still sung in many areas of Japan today. The words of Gōshū ondo vary from area to area and are generally modified to accord with local context. As Nakagami himself has noted, however, Kyōdai shinjū, the Gōshū ondo of Kasuga, is not a song about Kasuga. ${ }^{49}$ 
When considering this uncharacteristic element of the Kasuga Kyōdai shinjū it is useful to have some knowledge of the geographic relationship between Kasuga, Shingū, Gōshū and Kyoto. As previously noted, Kasuga was one of the hisabetsu buraku in Shingū. Shingū is a central city of the Kumano region, an area isolated from the ancient capital by forests and mountains. Gōshū is a province that borders both Kyoto in the north and Kumano in the south and is traditionally known as a commercial area with a good water supply from Lake Biwa.

The interpretation of the Kyōdai shinjū ballad requires some understanding of the economic development of Meiji Japan, particularly the emergence of the silk industry. Nakagami points out that Kyōdai shinjū was probably brought to Kasuga by jokō (factory women) who worked in silk factories in Gōshū..$^{50}$ As the principal source of Meiji era wealth, the silk industry was a central feature of Japanese nationalism in an era which saw Japan struggle to achieve parity with the imperialist nations of the west. ${ }^{51} \mathrm{~A}$ former jokō recalled, 'We were often told (by the minister): "You (jokō) are the treasure of our country; Japan would be ruined without you because the silk industry constitutes the foundation of the Japanese economy."' 52 Initially, jokō were drawn from daughters of the elite. However, when increasing production saw the size of factories expand, the need for jokō ballooned..$^{53}$ As a result, many daughters of poor families, including the peasants of Kumano, were recruited as labour in the silk factories which, as production increased, became increasingly oppressive workplaces. ${ }^{54}$ Production continued into the post-war era, with Nakagami's eldest sister (a model for Akiyuki's eldest sister, Yoshiko) sent to a silk industry town in the 1950s. For Kasuga people, whose daughters often worked as jokō, Kyōdai shinjū perhaps had local significance through the evocation of a separated family or lover. Furthermore, Okiyo's self-sacrifice for her brother resonates with the jokōss self-sacrifice for her family and the nation.

While girls from impoverished families later comprised the silk factory labour force, in the early years of the industry 'factory girls' were the daughters of high-status families, proud of their contribution to the modern nation-state..$^{55}$ Given the way that keigo (honorific language) is used in the narrative, we can read Kyōdai shinjū, too, as a kishu ryüritan of the brother and sister from the Kyoto aristocracy: the heir of the family, Monten, who leaves for Gōshū to commit murder for his incestuous love for his sister, and Okiyo, who is sent to the mills and who sacrifices her life for her

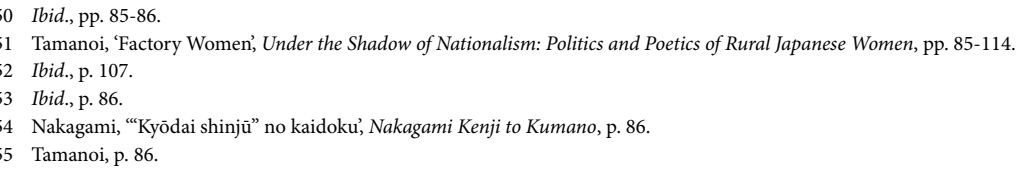


brother. ${ }^{56}$ To Nakagami, this tragic third person narrative gives the viewpoint of the community and the consequences for those who deviate from the norm by violating this social taboo. ${ }^{57}$

Nakagami interprets Kyōdai shinjū as a 'reverse' of the well-known kuniumi (birth of the country) narrative from the opening section of the Kojiki, which tells of the birth of Japan following the marriage of the god, Izanagi, ${ }^{58}$ and goddess, Izanami. This couple can, in fact, be considered as a brother and sister pair because they were born at the same time from heaven. In spite of the high status of the brother and sister in the Kyōdai shinjū narrative, Nakagami interprets the song as one of a failure of kuniumi by a Burakumin brother and sister:

When sung in the roji i.e. hisabetsu buraku, the kuniumi [narrative], which is performed by a brother and sister, becomes the narrative of a double suicide. In trying to give birth to a country, the couple give birth to a narrative that tells that they must die. The country to which this brother and sister give birth can be called an inverted country of darkness or a country in reverse. ${ }^{59}$

In the Akiyuki Saga, the sense of failure encapsulated in Kyōdai shinjū is depicted through Ikuo's death. ${ }^{60}$ Ultimately, Ikuo dies without being able to establish his own family.

In Karekinada, Akiyuki uses his transgression of the incest taboo to confront his father, hoping to invoke paternal ire:

Akiyuki spoke as though he were delirious, 'I fucked Satoko'. Akiyuki waited for the man let out a raging moan of pain [...]. This was, after all, his father. As the father, he should whip Akiyuki, knock Satoko down.

'It can't be helped. It happens all the time,' the man said. He laughed in a low voice. 'Don't worry about such things. Even if you two made a baby, even if it were an idiot child, it can't be helped. Although, if you have an idiot child, it's not easy for the mother.'

'I'll give birth to the idiot,' Satoko said.

\footnotetext{
56 Nakagami, who seems to have been unaware of the early involvement of girls from wealthy families in the silk industry, dismisses the use of keigo in this song as 'bad' (mecha kucha) grammar. Nakagami, “'Kyōdai shinjū” no kaidoku', Nakagami Kenji to Kumano, p. 88.

57 Ibid., p. 89.

58 Izanagi is the father of the Sun Goddess, Amaterasu, who is worshiped in Shintō as the founding ancestor of the imperial family. See 'Izanagi-no-mikoto' in Köjien, p. 116

59 Nakagami, 'Monogatari no keifu: Orikuchi Shinobu' (A Genealogy of Narratives: Orikuchi Shinobu), Nakagami Kenji zenshū 15, p. 215.

60 We might also note that this failure is encapsulated through the nervous breakdown of the sister, Mie, and her inability to give birth to Ikuo's offspring.
} 
'Do it, do it. It doesn't worry me if you have an idiot. I own land in Arima. One or two idiot grandchildren will be no trouble. ${ }^{31}$

As noted by a number of critics, Akiyuki's incest can be considered as a substitute for patricide. ${ }^{62}$ Yomota Inuhiko, for example, points out that Akiyuki justifies his incest with Satoko as his offence against his father. This is because, for Akiyuki, committing incest implies a violation of his father's biological order and a negation of Ryūzō as the paternal origin. ${ }^{63}$ Akiyuki expects to be reproached by his father for breaking the incest taboo. This is in accordance with the words of Kyōdai shinjū: 'if our parents heard of this, they would kill us. ${ }^{64}$ However, Ryūzō laughs and observes that, because he owns a vast expanse of land in the Arima region of Kumano, ${ }^{65}$ he doesn't care even if the pair have a child.

\section{Kishu-ryūri-tan 2: Saika Magoichi}

Nakagami applies a kishu ryūritan of a rebellious samurai to depict this outrageous father, Ryūzō. Arima is the setting of the kishu ryüritan of Saika Magoichi, the leader of the Saika $i k k i$, one of the major riots by the Kishū $I k k \overline{-}$-shü subjugated by Nobunaga. ${ }^{66}$ In the Akiyuki Saga, Nakagami gives Magoichi the family name of Hamamura, in order that this figure might have a direct connection to Ryūzō whose family name is also Hamamura. In the narrative, Nakagami embroiders the kishu ryūritan of Magoichi in order to depict Ryūzōs obsession with establishing a 'legitimate' origin for himself as Magoichi's descendant. The legend is located in Arima which, in addition to being the site of land owned by Ryūzō, is also the location of the 'underworld' in the myth of Izanagi and Izanami:

These mountains, these fields, were nothing more than stories fabricated in the fevered imagination of Hamamura Ryūzō, the King of Flies, the man with the big body and the snake eyes. Izanami died when her private parts were burnt as she gave birth to the god of fire. The cave in which she was interned after her death is less than five minutes by car from Ryūzōs Arima land ${ }^{67}$ The underworld of this myth is here. It is around this area. The man had built a monument there.

\footnotetext{
61 Nakagami, Karekinada, pp. 145-50.

62 Yomota, 'Kishu no shūen', Kishu to tensei: Nakagami Kenji, p. 169; Watanabe, 'Majikasa ni tsuite', Itoshisa ni tsuite, pp. 19-26; Iguchi, 'Kakusei to datsuryoku - Nakagami Kenji', Kiki to tōsō: Ōe Kenzaburō to Nakagami, pp. 85-89, and Karatani, 'Sanjussai, Karekinada e', Sakaguchi Ango to Nakagami Kenji, p. 254.

63 Yomota, 'Kishu no shūen', Kishu to tensei: Nakagami Kenji, p. 169.

64 Nakagami, Karekinada, p. 216.

65 Arima is the name of a town in Kumano City in Mie Prefecture. There is a description of Arima and the legend of Saika Magoichi in Nakagami's Kishü. See 'Arima', Kishū: kinokuni, nenokuni monogatari, pp. 139-48.

66 Saika $i k k i$ (The Riot in Saika) was an uprising against Nobunaga by believers of Ikkō shū (Jōdo shinshū) led by the son of the governor of Saika Castle, Saika Magoichi. In 1570, the principle temple of the Jödo shinshū denomination, Ishiyama-hongan-ji, clashed with Nobunaga. Magoichi took sides with the temple and rioted against Nobunaga. The riot was subdued in 1585 by Nobunaga's successor, Hideyoshi. See 'Saika ikki', Nihon daihyakka zensho.

67 The cave, traditionally said to be the grave of Izanami, is in Hanano-iwaya Shrine and is dedicated to Izanami and her fire-god son, Kagutsuchi-no-

mikoto. See Hana-no-iwaya jinja (Hana-no-iwaya Shrine).
} 
That stone monument was his penis, eternally erect. It was his wish for immortality which would never wither or decay. [...] In his mind, there was Magoichi who was defeated, whose villages in Ikkō shū were burnt to the ground and whose followers - including women and children - were murdered by Oda Nobunaga's troops. Magoichi came limping down the mountain with a small group of followers. [...] To the light, to the sea. It was the wish of the man's forefather. The uprising had been a clash between those who believed and those who didn't. The Buddha was with the vanquished. The place where there was light and sea was the final paradise where one could live with the Buddha. ${ }^{68}$

For Ryūzō, the Arima property signifies that he has inherited Magoichi's will to establish a 'futsukoku' (the pure land for followers of the Buddha). ${ }^{69}$

In the 'underworld' of the kishu ryūritan, all the conventions of mainstream society are inverted. Magoichi was a defeated hero, lame in one leg and blind in one eye. ${ }^{70}$ Ryūzō's acceptance of 'idiot' children who are born from incest is in opposition to the original Kojiki myth of kuniumi, in which Izanagi and Izanami refuse to accept imperfect children who are instead floated away downstream by their parents. ${ }^{71}$ Philippi suggests that the deformed or unworthy children that Izanagi and Izanami reject are the result of the parents erring in the ritual of conjugal intercourse. ${ }^{72}$

Ryūzō, however, is depicted as a man who laughs away traditional narratives which were established through the conventions of the hegemonic centre. The death of the couple in Kyōdai shinjū demonstrates the penalty demanded by the centre from those who transgress. Ryūzō, however, rejects these hegemonic narratives in favour of establishing his own glorious nation by affiliating with Magoichi, the defeated hero of the Arima kishu ryuritan, in a way that removes the usual stigma of subalternity attached to that hero. In this sense, Ryūzō's ambition resonates with Gramsci's assertion that the history of subaltern groups is of equal value to the authorised history of the mainstream.

Like many elites, Akiyuki's father re-invents his own history - as Magoichi's ancestor - by bribing local historians to fabricate proof of the legend. This proof involves creating a false 'cycle' of a subaltern association with the roji and also the creation of a false genealogy of Arima. Having identified the traces of subalternity in his background, he then re-interprets these traces to signify success in his own domain. Through

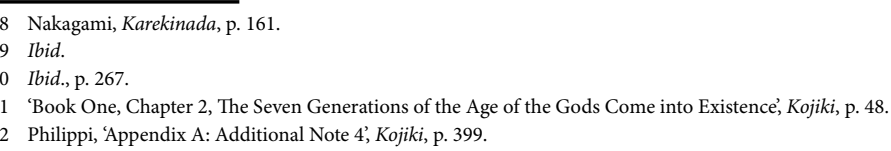


depicting the affiliation by the subaltern characters in the Akiyuki Saga to the various kishu ryüritan, Nakagami effectively 'writes back' to the hegemonic centre which has marginalised Kishū Kumano.

As evident from his characterisation of Ryūzō, Nakagami regards Burakumin oral folklore such as kishu ryüritan as conveying the trace of Burakumin subalternity imposed by the centre. He later confirms this view after a trip to Ise, the home of Japan's principal shrine. Following a visit to the shrine library, where he found over two hundred thousand books containing records of the activities of past royal families, Nakagami became convinced that imperial authority in Japan rested upon the 'written word', declaring that 'the emperor reigns the country by thousands of words and letters.'73 Since the tradition of writing literature such as waka (Japanese poetry) and monogatari (tales) had been monopolised by the nobility since ancient times, Nakagami regards the illiterate Burakumin as a people who had long been abandoned by tradition. ${ }^{74}$

As a novelist who uses the Japanese language, Nakagami reveals his ambivalence towards the writer's imperative of making use of the 'written word' which, since the time of the Kojiki, has been traditionally used to justify and reinforce the hegemony of the centre. As a Burakumin novelist, Nakagami considers that using the 'written word' to 'write back' to the hegemonic centre is paradoxical. This is because the act of writing naturally implies a celebration of the same hegemonic centre that marginalised the Burakumin.

Nakagami considers, on the other hand, that Burakumin oral culture is independent from the emperor's sovereignty over written language. ${ }^{75} \mathrm{He}$ asserts, furthermore, that the 'spoken word' such as folklore has the 'mythical function' to challenge the written word and the system that the emperors of ancient times established by compiling the book of mythologies. ${ }^{76}$ The fact that, unlike the usual Gosh $\bar{u}$ ondo, Kyōdai shinjū was not modified to the local Kasuga context suggests the socio-historical complexity of relations between the hisabetsu buraku and the centre. While the song's keigo implies an elite background to the tragic couple, the brother's incestuous love for his sister strongly interrogates the hegemonic family system that is also subverted by family relations in the roji. Through giving voice to the plight of Monten and Okiyo as expressed in this kishu ryüritan, and in portraying the tragic consequences of Monten's love, Nakagami also reveals the hidden voice of the subaltern members of the roji and the oppressive social penalties they incur.

\footnotetext{
Nakagami, 'Ise', Kishū: kinokuni, nenokuni monogatari, p. 189.

4 Nakagami, 'Watashi wa <nihonjin> nanoka' (Am I <a Japanese>?), Nakagami Kenji hatsugen shūsei 6, p. 340.

5 Nakagami, 'Ise', Kishū: kinokuni, nenokuni monogatari, pp. 193-94.

76 Nakagami, 'Mono to kotoba (Things and the Word), Nakagami Kenji to Kumano, p. 23.
} 


\section{Conclusion}

Borrowing the post-colonial concept from The Empire Writes Back of 'writing back' to the hegemonic centre, the paper analysed Nakagami's 'Misaki' and Karekinada with an emphasis on his representation of the hidden subaltern voice. This analysis began with a discussion of the importance of understanding the 'otherness' and long-established marginality of the Kishū Kumano region in which the narrative was set. For Nakagami, fictional representation of the lives and stories of the people from this area - particularly those who live in the dispossessed area he refers to as the roji - was a strategy to reveal the hidden subaltern voice.

As previously noted, another important subject of the Akiyuki saga is the dismantlement of the roji - the Burakumin homeland - during the modernisation and urbanisation of peripheral areas throughout Japan that occurred in the 1970s and 1980s. Nakagami's work often displayed his view that dismantlement of the hisabetsu buraku in the name of urbanisation did not signify the effacement of discrimination. Rather, this process merely made Burakumin more invisible. Despite modernisation, the Burakumin are still stigmatised as 'subaltern'.

Nakagami's narratives critique the mainstream ideology that seeks to exclude social 'difference' and efface 'otherness' such as the Burakumin presence. Nakagami's use of intertextuality with the oral kishu ryüritan folklore and literary canons in his narratives displays the 'difference' between the silenced subaltern voice and the mainstream conventions which have produced the marginalised since ancient times. As Gramsci notes, subaltern narratives include the trace of the oppressive activity of the mainstream. Through the process of 'writing back' to the hegemonic centre, Nakagami seeks both to preserve 'difference' from effacement by the mainstream society and to make audible the silenced subaltern voice. 


\section{References}

'Arima no miko', in Daijisen (Tokyo: Shōgakukan, 1995), p. 90.

Ashcroft, B., Griffiths, G. and Tiffin, H., The Empire Writes Back: Theory and Practice in Post-Colonial Literatures (London: Routledge, 1989).

-_- Post-Colonial Studies: The Key Concepts (London: Routledge, 2002).

Barry, P., Beginning Theory (Manchester: Manchester UP, 1995).

'Bon', in Shinmura, I. (ed.), Kōjien (Tokyo: Iwanamishoten, 1983), p. 2224.

Buraku Liberation League Tokyo. Retrieved 1 September 2010, from http://www.asahi-net.or.jp.

Cornyetz, N., Dangerous Women, Deadly Words: Phallic Fantasy and Modernity in Three Japanese Writers (California: Stanford UP, 1999), pp. 206-25.

Etō, J., 'Bungei jihyō: Showa 52 nen 2 gatsu', in Karatani, K. (ed.), Gunzō Nihon nosakka 24: Nakagami Kenji (Tokyo: Shōgakukan, 1996), pp. 142-45.

Gramsci, A., 'Notes on Italian History', in Quintin Hoare, Q., and Smith, G. N. (ed.), Selections from the Prison Notebooks (London: Lawrence and Wishart, 1971), pp. 52-120.

Guha, R., Subaltern Studies: Writing on South Asian History and Society, vol. 1 (Delhi: Oxford UP, 1982).

'Hana no iwaya jinja', Hana no iwaya jinja. Retrieved 1 September 2010, from http://www.hananoiwaya.jp.

Iguchi, T., Kiki to tōsō: Ōe Kenzaburō to Nakagami Kenji (Tokyo: Sakuhinsha, 2004).

'Ikkō ikki', in Daijisen (Tokyo: Shōgakukan, 1995), p. 161.

'Izanagi no mikoto' in Shinmura, I. (ed.), Kōjien (Tokyo: Iwanami shoten, 1983), p. 116.

Karatani, K., Sakaguchi Ango to Nakagami Kenji (Tokyo: Kōdansha bungei bunko, 2006).

Karatani, K. and Sekii, M., 'Tōsō suru chisei to bungaku', in Sakaguchi Ango to Nakagami Kenji (Tokyo: Kōdansha bungei bunko, 2006), pp. 326-63.

Karlsson, M., The Kumano Saga of Nakagami Kenji (Edsbruck: Akademitryck AB, 2001).

'Kishu ryūritan', Nihon daihyakka zensho. Retrieved 1 September 2010, from http://100.yahoo.co.jp.

'Kishu ryūritan', in Shinmura, I. (ed.), Kōjien (Tokyo: Iwanamishoten, 1983), p. 575.

Kojiki (Tokyo: Tokyo UP, 1968).

'Kojiki', in Daijisen (Tokyo: Shōgakukan, 1995), p. 960.

Koyama, S., Ryōsai kenbo shisō no seiritsu (Tokyo: Keisō shobō, 1992).

Nakagami, K., 'The Cape', in The Cape and Other Stories from the Japanese Ghetto (California: Stone Bridge Press, 1999), pp. 1-91.

_-_, Chi no hate, shijō no toki (Tokyo: Shōgakukan, 2000). 
New Voices Volume 5

_-_, 'Fūkei no mukō e: Kankoku no tabi', in Karatani, K., Asada, A., Yomota, I. and Watanabe, N. (ed.), Nakagami Kenji zenshū 15 (Tokyo: Shūeisha, 1996), pp. 57-100.

___, 'Interview: Usha Subraminian', in America, America (Tokyo: Kadokawa shoten, 1992), pp. 208-24.

-_-, Karekinada (Tokyo: Kawade bunko, 1995).

—__, Kishū: Kinokuni, nenokuni monogatari (Tokyo: Kadokawa shoten, 2009).

-_-, "Kyōdai shinjū' no kaidoku', in Karatani, K. and Watanabe, N. (ed.), Nakagami Kenji to Kumano (Tokyo: Ōta shuppan, 2000), pp. 76-92.

_—_, 'Misaki', in Misaki (Tokyo: Bunshun bunko, 2000).

-_-, 'Mono to kotoba', in Karatani, K. and Watanabe, N. (ed.), Nakagami Kenji to Kumano (Tokyo: Ōta shuppan, 2000), pp. 18-26.

_-_, 'Monogatari no keifu: Orikuchi Shinobu', in Karatani, K., Asada, A., Yomota, I. and Watanabe, N. (ed.), Nakagami Kenji zenshū 15 (Tokyo: Shūeisha, 1996), pp. 178-230.

——_, 'Nihon no futatsu no gaibu', in Karatani, K., Asada, A., Yomota, I. and Watanabe, N. (ed.), Nakagami Kenji zenshū 15 (Tokyo: Shūeisha, 1996), pp. 583-85.

-_-, 'Ō no shussei no nazo', in Karatani, K. and Watanabe, N. (ed.), Nakagami Kenji to Kumano (Tokyo: Ōta shuppan, 2000), pp. 58-75.

_-_, 'Watashi no naka no nihonjin - Ōishi Seinosuke, in Yume no chikara (Tokyo: Kadokawa shoten, 1976), pp. 41-47.

- - - 'Watashi wa <nihonjin> nano ka', in Karatani, K. and Suga, H. (ed.), Nakagami Kenji hatsugen shūsei 6 (Tokyo: Daisan bunmeisha, 1999), pp. 337-45.

Nakagami, K. and Takahashi, T., 'Roji to shinwateki sekai no kōgaku', in Karatani, K. and Suga, H. (ed.), Nakagami Kenji hatsugen shūsei (Tokyo: Daisan bunmeisha, 1999), pp. 87-106.

Nakagami, K. and Tomioka, T., 'Hatsunetsu suru Ajia', in Karatani, K. and Suga, H. (ed.), Nakagami Kenji hatsugen shūsei 5 (Tokyo: Daisan bunmeisha, 1999), pp. 230-35.

Noma, H., Seinen no wa. Vol. 1-5 (Tokyo: Iwanami bunko, 2005).

Noya, F., 'Nakagami Kenji to Sekai bungaku', in Kokubungaku kaishaku to kanshō: Bessatsu (Tokyo: Shibundō, 1993), pp. 32-37.

Orikuchi, S., Orikuchi Shinobu zenshu 4: Nihon bungaku no hassei josetsu (Tokyo: Chūō kōronsha, 1995).

Philippi, D. L., 'Appendix A: Additional Note 4', in Kojiki (Tokyo: Tokyo UP, 1968), p. 399.

Said, E. W., 'Foreword', in Guha, R. and Spivak, G. C. (ed.), Selected Subaltern Studies (Oxford: Oxford UP, 1988), pp. v-x.

'Saika ikki', in Nihon daihyakka zensho. Retrieved 1 September 2010, from http://100.yahoo.co.jp.

Shimazaki, T., Hakai (Tokyo: Shinchō bunko, 2005).

Sophocles, 'Electra', in The Internet Classics Archive. Retrieved 1 September 2010, from http://classics.mit.edu/Sophocles/electra.html. 
‘Taigyaku jiken’, Nihon daihyakka zensho. Retrieved 1 September 2010, from http://100.yahoo.co.jp.

'Taira', in Daijisen (Tokyo: Shōgakukan, 1995), pp. 1616-17.

Takazawa, S., Nakagami Kenji jiten (Tokyo: Kōbunsha 21, 2002).

——_, Hyōden: Nakagami Kenji (Tokyo: Shūeisha, 1998).

Tamanoi, M. A., 'Factory Women', in Under the Shadow of Nationalism: Politics and Poetics of Rural Japanese Women (Honolulu: Hawaii UP, 1998), pp. 85-114.

Teraki, N., 'The Buraku Question', Buraku Liberation News. Retrieved 1 September 2010, from http://blhrri.org/blhrri_e/news/new104/new10402.htm.

Tipton, E. K., Modern Japan: A Social and Political History (London: Routledge, 2002).

'Uma No Hone', in Shinmura, I. (ed.), Kōjien (Tokyo: Iwanamishoten, 1983), p. 228.

Watanabe, N., Nakagami Kenji ron: Itoshisa ni tsuite (Tokyo: Kawade shobō, 1996).

-_- Nihon kindai bungaku to <Sabetsu> (Tokyo: Ōta shuppan, 1994).

Yomota, I., Kishu to Tensei: Nakagami Kenji (Tokyo: Shinchōsha, 1996).

Zimmerman, E., 'In the Trap of Words: Nakagami Kenji and the Making of Degenerate Fictions', in Snyder, S. and Gabriel, P. (ed.), Oee and Beyond: Fiction in Contemporary Japan (Honolulu: Hawaii UP, 1999), pp. 130-52.

-_-, Out of the Alleyway: Nakagami Kenji and the Poetic of Outcaste Fiction (Cambridge, Mass. and London: Harvard UP, 2007). 


\section{Appendix: Akiyuki's Family Tree}

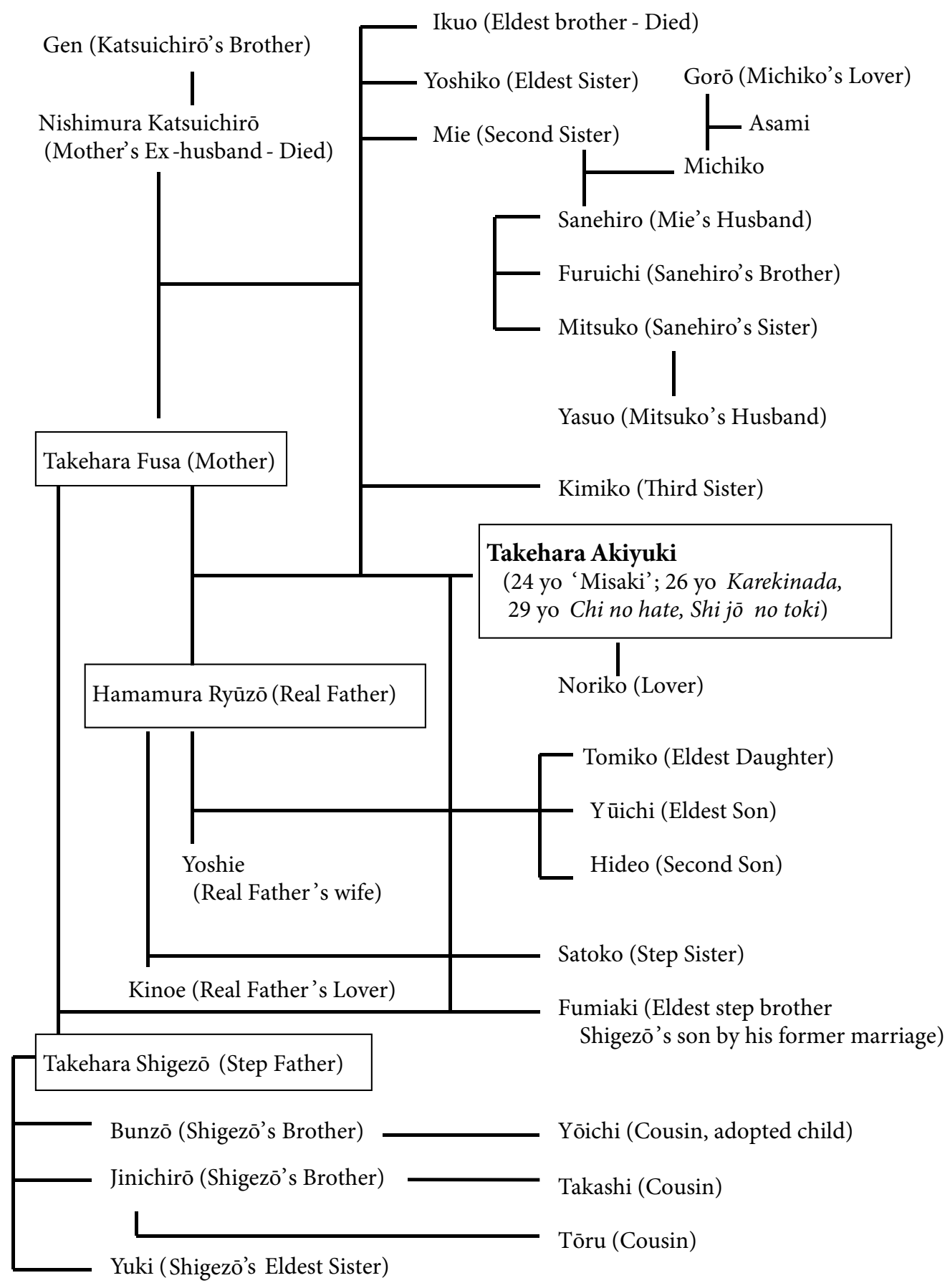

